Article

\title{
Culture Development for Sustainable SMEs: Toward a Behavioral Theory
}

\author{
Nuttasorn Ketprapakorn ${ }^{1}$ and Sooksan Kantabutra ${ }^{2, *}$ \\ 1 School of Business, University of the Thai Chamber of Commerce, Bangkok 10400, Thailand; \\ nuttasorn_ket@utcc.ac.th \\ 2 Center for Research on Sustainable Leadership, College of Management, Mahidol University, Bangkok 10400, Thailand \\ * Correspondence: sooksan.kan@mahidol.ac.th
}

Received: 8 April 2019; Accepted: 6 May 2019; Published: 7 May 2019

\begin{abstract}
The present study derives culture development practices among "sustainable" small and medium enterprises (SMEs)that adopt the Thai philosophy of the sufficiency economy. It adopts multiple data collection methods including non-participant observations made during visits to five "sustainable" enterprises, and references internal and published documents among other information about the case enterprises, including annual reports, previous studies about the companies and news reports. In-depth interview sessions were held with top management team members and employees, including CEOs or MDs, and division/functional heads. The "grounded theory" is adopted as an approach to analyze the data. The analysis reveals six emerging organizational culture development practices: identifying virtues, social and environmental responsibility and innovation as core values; leaders acting as models according to these values; growing their own managers to continue their corporate cultures; designing communication channels to emphasize the core values among employees; using the core values as criteria to recruit new employees; avoiding employee layoff to preserve the core values even in times of financial crisis. Limitations and future research directions to develop a behavioral theory of sustainability culture in organizational settings, as well as managerial implications are discussed.
\end{abstract}

Keywords: corporate sustainability; sustainability culture; sufficiency economy; culture development; Thailand

\section{Introduction}

Sustainable development has been of great interest among corporate leaders since the 1980s due to the rapidly changing business environment that has had a profound impact on the corporate world [1]. In particular, the prevailing management approach of short-term maximization of profitability has not arguably lead to the wellbeing and happiness that societies hope to have as it often takes advantage of employees and society by, for example, cost-cutting in training and investment for protecting the environment. Such a practice often leads to an organizational inability to sustain itself. Is there any other alternative?

The sufficiency economy philosophy, often adopted by sustainable Thai enterprises, regards employees as a prime asset which can always be developed. Sustainable Thai enterprises develop a culture in which employees are affectively engaged in corporate activities, leading to long term sustainable success. Empirical evidence suggests that engaging employees was associated with client satisfaction, staff productivity, profits, staff retention and safety [2]. Research into 65 business enterprises from a range of industries indicates that the top $25 \%$ on an engagement index yielded a larger return on assets (ROA) and profitability [3]. More surprisingly, it yielded more than double the shareholder value in relation to the bottom $25 \%$ [3]. 
In the present study, the sufficiency economy philosophy is introduced as an Asian approach to corporate sustainability. The study examines practices of five "sustainable" SMEs in Thailand, each with an impressive record, with an objective to derive culture development practices that supposedly bring about an affectively engaged workforce, leading to sustainable success. Relevant literature, methodology, findings, implications for corporate leaders, and future directions for researchers, particularly those hoping to develop a practical theory of sustainability culture in organizational settings, are discussed below.

\section{Background Literature}

The philosophy of sufficiency economy was derived from royal preaching of His Majesty King Bhumibol Adulyadej during his reign of 58 years [4]. It promotes the middle path as the overriding principle for Thais to guide their ways of life. It can be adopted at the individual, family, and community levels. The philosophy with the need for built-in resilience is an alternative balanced development strategy for the nation to effectively encounter the forces of globalization.

When numerous organizations went bankrupt during the 1997 Asian economic crisis, His Majesty reiterated the sufficiency economy philosophy as a strategy towards economic recovery and a resilient and sustainable economy [5]. Coincidently, the emergence of the philosophy responded to an international demand among theorists and model developers for a new version of the firm theory that takes into account the stakeholder relationship. This newly developed theory has gradually replaced the prevailing theory of the firm with profitability as the prime goal of business [6-11].

"Sufficiency economy is a philosophy that stresses the middle path as an overriding principle for appropriate conduct by the populace at all levels. This applies to conduct starting from the level of families to communities and to the nation in terms of development and administration, so as to modernize in line with the forces of globalization. 'Sufficiency' means moderation, reasonableness, and the need for self-immunity to protect from impacts arising from internal and external change. To achieve sufficiency, an application of knowledge with due consideration and prudence is essential. In particular, great care is needed in the utilization of theories and methodologies for planning and implementation in every step. At the same time, it is essential to strengthen the moral fiber of the nation, so that everyone, particularly public officials, academics, and business people at all levels, adheres first and foremost to the principles of honesty and integrity. In addition, a way of life based on patience, perseverance, diligence, wisdom and prudence is indispensable in creating balance and in coping appropriately with critical challenges arising from extensive and rapid socioeconomic, environmental, and cultural changes in the world."

Sufficiency Economy Philosophy ([12], p.128)

Three components and two underlying conditions constitute the philosophical framework [12]. "Moderation", "reasonableness" and "resilience", or requirement for immunity, i.e., the ability to respond to internal and external shocks are the core, while "knowledge" and "morality" are the two underlying conditions. The underlying conditions are to determine whether one is moderate, reasonable and resilient.

The adoption of the sufficiency economy demands great care in planning, applying knowledge and implementing the plans. Moreover, it requires people to be honest and ethical while living their lives virtuously, perseveringly, harmlessly and generously. Indeed, the philosophy acts as a guide for people at all levels to conduct their lives. It can also be applied to business organizations [12]. The philosophy of the sufficiency economy is endorsed by the stakeholder theory of the West where values and morality are highlighted as the core of running a successful enterprise [13].

Since businesses adopting the philosophy of sufficiency economy are expected to be sustainable, the philosophy can be regarded as an approach to corporate sustainability. Internationally, sustainable leadership has been introduced as a western approach to corporate 
sustainability. It emphasizes corporate responsibility and moral commitment for various stakeholders $[14,15]$ by assuming that doing so leads to the integrity of brand and reputation, high customer satisfaction, strong financial performance, and therefore improved long-term value for multiple stakeholders, including shareholders. Sustainable enterprises pay great attention to a wide range of stakeholders and their relationships with them by recognizing their concerns and needs $[16,17]$. These strong relationships are based upon trust, mutual respect, support, as well as genuine understanding. They do so to avoid social crises and improve the society.

Research investigating sufficiency economy businesses is limited. Built on research by Puntasen et al. [18], the business practices of five large listed companies were examined by Kantabutra et al. [19] to determine if their business practices were consistent with sufficiency economy business practices $[18,20]$. The resulting sufficiency economy leadership practices were derived, including genuine concern for employees and development of a strong organizational culture characterized by ethics, perseverance, diligence and innovation.

Later research exploring a Thai hospital [21], a leader in the treatment and prevention of endocrine disorders in Thailand, reports consistent findings with the ten sufficiency economy leadership practices. Two other studies explored two "sustainable" Thai SMEs, both leaders in their niche markets [22,23]. Both studies reveal similar findings to the ten practices. Most recently, a study by Kantabutra and Thepa-Apiraks [24] explored the business practices of Kasikornbank, a major financial services provider in Thailand, to identify sustainable business practices. Six were derived: adopting a long-term orientation; offering people priority; innovating throughout the organization; being socially responsible; preparing for uncertainty and change; and behaving ethically. These identified practices are consistent with the practices identified by Kantabutra et al. [20].

Another similar study outside Thailand explored the largest air-flight agency in South Vietnam employing about 60 employees [25]. Similarly, findings indicate that the sample adopted a long-term orientation, promoted internal staff development, nurtured a strong organizational culture, innovated incrementally and radically, was socially and environmentally responsible and acted ethically.

According to the literature, the organizational culture plays a vital role in sustaining an enterprise as it ensures sustainability, given that organizational culture outlives any one individual [26]. Organizational culture is also a firm's competitive advantage as it takes time to develop and is more difficult to imitate than for example access to financial capital or installing the latest equipment. Therefore, enterprises with a strong culture are highly competitive.

Sustainable SMEs in Thailand foster a strong corporate culture, shared values or beliefs, e.g., [27]. Such a culture provides the justification for people's actions and helps employees to determine desirable behaviors despite no close monitoring and control by managers. Indeed, an organizational culture reflects soft or unwritten rules of a company. Organizational culture can also be considered as a form of intellectual property or an intangible asset [27]. A positive culture works as an intangible asset, while a negative culture works as a drag on performance, potentially leading to an organization's decline or demise. Starbucks and AIG Insurance are two examples of the dual role of corporate culture. While Starbucks is a classic case of a strong and productive culture, or an economic asset, AIG is also a classic case of a strong negative culture which leads to a rapid downturn in financial value.

Previous research [28] suggests that values contributing to corporate sustainability included entrepreneurship, hard work, excellence, prudence, profitability and quality. Similarly, the values underlying sustainable Thai companies are often ethics, innovation, moderation, customer satisfaction, top quality, excellence, environmental preservation and people priority [21]. However, in order to align individual and corporate values, employees need a long time. For this reason, creating a strong organizational culture is not simple where employee retention is low, and individual and corporate values are not already adequately aligned.

Derived from the literature review, the following theoretical framework (Figure 1) is developed. Theoretically to sustain an organization, virtuous organizational members with accumulated knowledge 
and experience, relevant insights or wisdom are required. Moreover, they should make a decision as informed by moderation, reasonableness and need to develop immunity, a resulting action of which is to develop a strong organizational culture. According to the literature [29-32], corporate sustainability, as measured by competitive performance culturally, socially, environmentally and economically, immunity and resilience can be expected. In part, a strong organizational culture leads to corporate sustainability.

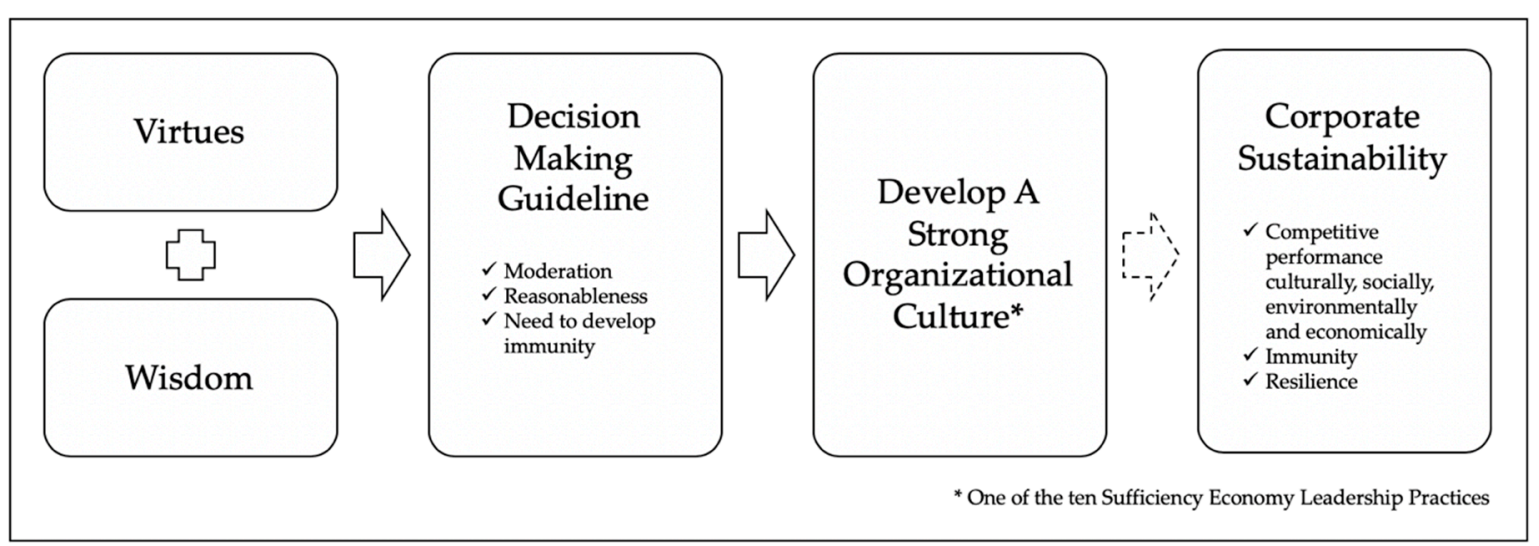

Figure 1. The Sufficiency Economy Philosophy framework.

Previous qualitative research exploring sufficiency economy businesses is often about identifying general business practices for sustainable enterprises. Little, if any, has specifically identified culture development practices. Therefore, the present study attempts to identify culture development practices in sustainable enterprises, with the sufficiency economy philosophy as the research framework. More critically, since there is a lack of behavioral theory of sustainability culture in the corporate sustainability field, we also attempt to propose some directions to develop such a theory, a major contribution of the present study. How data is collected and analyzed is discussed next.

\section{Research Methodology}

The present study develops a set of open-ended questions on how a "sufficiency economy" corporate culture is formed. A few examples of the questions include:

1. Would you describe your corporate culture?

2. How has your corporate culture been nurtured?

3. How do you practice your corporate values?

We also adopted a variety of data collection methods. Non-participant observations made during visits to five enterprises and documentation and other information about the case enterprises such as annual reports, previous research about the enterprises and news reports are among them. Information from these documents is used to provide additional data and to verify the original data we collected. The top management team members and employees, including chief executive officers (CEOs) or managing directors (MDs) and division/functional heads, depending on each case company's permission, were interviewed at length. All were chosen on a convenient basis. We used note-taking, videotape or tape-recording techniques to record interviews and observations (with participant permission). Accordingly, critical incidents and reflections were derived to generate qualitative data. Probes were adopted to explore and validate interview answers further.

The five case enterprises are chosen because they have demonstrated their capability to survive financial and social crises, such as the 1997 Asian economic crisis and the 2008-2009 subprime crisis, successfully and maintain a market leadership in their relevant industries, and can be justified as sufficiency economy businesses because their business philosophies are consistent with the sufficiency economy philosophy. Their company backgrounds are demonstrated in Table 1 below. 
Table 1. Background of the sample SMEs.

\begin{tabular}{cccccc}
\hline & Farm Chokchai & PlanCreation & Phung Noi Bakery & Dhanabadee Ceramic & Nithi Foods \\
\hline Province & Nakornrachasrima & Trang & Changmai & Lampang & Chiangmai \\
\hline Type & $\begin{array}{c}\text { Agribusiness and } \\
\text { tourism }\end{array}$ & Wooden Toys & Bakery & $\begin{array}{c}\text { Decorative ceramic } \\
\text { ware }\end{array}$ & $\begin{array}{c}\text { Spices and } \\
\text { seasoning }\end{array}$ \\
\hline $\begin{array}{c}\text { Year of } \\
\text { establishment }\end{array}$ & 1957 & 1981 & 1984 & 2010 & 1998 \\
\hline $\begin{array}{c}\text { Estimated no. } \\
\text { of employees }\end{array}$ & 1100 & 800 & 700 & 195 & 50 \\
\hline
\end{tabular}

To identify sufficiency economy culture development practices, the present study's analysis approach is informed by the "grounded theory" approach [33]. Adopting the "grounded theory" approach, the open coding technique was first used to identify data themes emerging from all of the collected data, involving analyzing observation notes, interview transcripts, reflection notes, and relevant documents line by line, paragraph by paragraph [34]. Later, the researchers aggregated these codes into concepts, named or labeled as open codes. The coding process normally brings about multiple open codes $[33,35]$.

The researchers next were required to recombine closely linked and overlapping open codes into aggregated key concepts [34]. In the present study, the focal core code is related to culture for corporate sustainability, the central phenomenon naturally emerging from the axial coding process. All other core codes are related in some way to the focal core code of sustainability culture. The researchers were required to identify the relationships [35]. These core codes are essentially influencing concepts and were identified as culture development themes. The focal core code, core codes and their relationships are discussed in the next.

It must be noted that the grounded theory approach adopts the comparing, contrasting, cataloguing and classifying process. This process is iterative over a year to derive emerging themes as the sufficiency economy culture development practices, which demands supportive rationales and significance [33]. Such an inductive process allows the researchers to take into account the always changing surrounding context. Therefore, the resulting emerging themes reflect a continuous process, as opposed to an event that is true only at a given time (e.g. survey of consumer attitudes for a service).

\section{Discussion of the Findings}

Given the vast amount of collected data, six themes about culture development have emerged. Each has its own supporting evidence discussed and grounded with the existing literature below. Moreover, literature-informed theoretical assertions between the practices and prospect of corporate sustainability are derived for a future theory building purpose, a significant contribution of the present study.

\subsection{Sustainable Thai SMEs Identify a Variety of Virtues, Social and Environmental Responsibility and Innovation as Their Core Values}

Unlike typical companies where core values are simply written statements, sustainable Thai enterprises live their core values. They regard social and environmental responsibility as a given by investing in it, often beyond the legal or standard requirement. They also take into consideration such values as generosity, perseverance, and social and environmental responsibility as part of employee performance evaluation. Employees are encouraged to suggest their ideas. They also have a system to promote innovation. Social and environmental responsibility underpins the organizational philosophy of these sustainable Thai SMEs. Whenever there is a demand to invest in protecting the society and environment, these SMEs do so willingly. Although there are obvious financial gains from being a good organizational citizen, they invest because it is the "right thing to do".

"We brainstormed with staff for the shared values that help create Nithi Foods' organizational culture. We started with the existing values, after which we did the interview (with staff). 
Finally, we came up with what we called Nithi Foods 3C. The 3C stands for credible, creativity and care."

Managing Director, Nithi Foods

“My mother always tells us that perseverance makes us virtuous. Anyone who perseveres will prosper. This includes our employees. No matter what happens, we have to persevere to be virtuous. We must help each other, whether among staff or even their relatives."

Human Resource Department Manager, Phung Noi Bakery

"I think the culture at Plan Toys is planet preservation, whether it is about products or whatever. We utilize everything efficiently. That is why each employee does not do anything big but do some little things to help such as plastic bags reduction. Instead, we use 'Pin To' (tiffin carriers)"

HR staff, Plan Creation

"I think we have a cooperative culture. When we have an urgent task, everyone cooperates willingly. Another part of our culture is problem-solving. We like to help each other in tackling a problem ... I think this is part of our culture that rooted deeply in our organization."

Executive Vice President \& Human Resources Strategist, Farm Chockchai

"We groom our staff to be honest with themselves, customers and co-workers. Even with subcontractors who sell and buy our products, we have to be honest. To be in the society, we have to develop ourselves continuously. We always improve our products and innovation in the company. Finally, we cannot stand alone. We are happy, so is the society ... This is our core value."

Managing Director, Dhanabadee Ceramic

These findings are endorsed by previous research at Kasikornbank [24]. With social responsibility and ethics as core values, employees were always a key driver of the success of the bank, where trust and confidence from various sectors were earned, both domestically and internationally. The ethical principles and social responsibility were clearly evident in many aspects of the bank's operation, translating into a concern for a wide range of stakeholders, not just shareholders. Ethical employees enhanced the service quality and minimized risks associated with non-transparency issues.

Theoretically, when SMEs promote a variety of virtues, such as social and environmental responsibility and innovation as their core values, employees are encouraged to produce sustainable and innovative products and services [22,29], which responds to the increasing market demand and allows the companies to enhance their organizational capacity to maintain a market leadership position. Sustainable and innovative products and services result in a larger market share and profitable growth, bringing healthy corporate finance which in turn immunes the companies in times of crisis. Therefore, the following theoretical assertion is developed for future theory development.

Proposition 1. Promoting a variety of virtues as core values leads to enhanced corporate sustainability prospects through its organizational capacity to maintain a market leadership position and to deliver strong financial performance.

\subsection{Top Managers Always Act as a Role Model According to These Values to Show Their Employees How They} Should Live the Values

Top managers at these SMEs behave consistently with their values, because consistent behavior reflects leadership's integrity defined as having desirable character and conviction, and being trustful and trustworthy. Leadership's integrity is clearly a critical attribute in superiors whose subordinates 
look for and admire. Integrity is important as employees recognize too soon to what extent their managers essentially stand behind the values, within their minds and hearts. The moment the employees begin to question the seriousness of their managers towards the values, cynicism is invariably the consequence. This explains how a top manager's commitment to the values is closely related to employees' trust in the top managers. An untrusted manager is unlikely to achieve commitment from the employees to shared goals.

"Our managers work very strictly. They act as a role model. They are polite and do not cheat on tax. They are responsible to clients by ensuring that their suppliers are ones that look after hygiene of their individual employees. It is common that such suppliers cost higher, we still consider it worthwhile."

Marketing Department Manager, Nithi Foods

"When we were to buy a car, we want an electric car. But an electric car was not available so we bought a hybrid car instead so we could show employees how to live a core value of environmental responsibility."

Managing Director, Plan Creation

"It (the organizational culture) comes from the bosses. My bosses act as a role model. The gentleman-ness is from the founder, and the moral integrity is from his wife. The son (the top manager now) is a model for a new generation with creativity and enthusiasm. This pushes us to think creatively. It is organizational culture."

Retail Business Director, Farm Chokchai

"She is a good leader. She believes a good example is more valuable than preaching. She is always an example of perseverance. Although she is the top manager, she works out every detail, much more than anyone in this company"

Administration Department Manager, Phung Noi Bakery

“I am happy as part of this journey. In the past, Mr. Panasin (Managing Director) went out to get an order. I always went with him. I am proud that he never leaves me. I love this place. Whatever I can do to help, I will ... I love this place like my home. It is where we make our living."

\section{Staff, Dhanabadee Ceramic}

These findings are also supported by previous research at True Corporation, a convergent lifestyle enabler [36]. The president and CEO acted as a role model particularly during a time of crisis to help to maintain a high level of morale among staff, consistent with its core value of four Cs: caring, creative, credible, and courageous.

In theory, the role model representation of these values by top leaders are considered as a form of motivation [37] as employees understand how it looks and feels to live these values. When employees see their top leaders practicing these values, they are intrinsically motivated and would like to live the values too. Therefore, both top leaders and their employees are molded together to work towards organizational goals. This unity often helps to enhance organizational capacity to endure a crisis, where employees support each other in going through the crisis [29]. Accordingly, the following proposition is formed for future theory development.

Proposition 2. Leadership role modeling leads to enhanced corporate sustainability prospect through a high level of motivation among staff and organizational effectiveness. 


\subsection{Sustainable Thai SMEs Prefer to Grow Their Own Managers to Continue Their Corporate Cultures}

Top management teams at these SMEs realize the need for a continuation of corporate culture and its effects on the company's performance particularly after a time of crisis. More critically at the top level, insider CEOs continue the culture, while outsider ones destroy it. The internal promotion also offers benefits of knowledge transfer and collective insights. Financially, it reduces recruitment costs. The prevailing practice of employing outsider executives is a major challenge to become and remain a sustainable company with a cohesive culture. By continuing their cultures and core values, the sustainable SMEs strive for innovation that allows them to respond to the changing external context. Organizational members are held together by this cohesive culture particularly when their businesses are going through crises.

"We promote internally and continuously develop people to meet the requirement of our expansion. Instead of grasping the opportunity and taking in new 10-20 employees at once, we rather gradually hire two or three new employees each year to grow together with our business."

\section{Managing Director, Nithi Foods}

"If a position requires specific skills, we will promote from within. We usually ask a functional director for opinions first and consider staff performance results and attitudes.... We recruited an external person only when a job required specific skills and we could not find an internal candidate, which is estimated at less than $20 \% "$

Assistant Director for Finance and Administration, Plan Creation

"At one point, we will have to find successors for all positions. The founder and people of his generation now are over 50 . We have to find successors who are about 40 and still active. But we do have criteria for successors."

\section{Executive Vice President, Farm Chockchai}

"This company has grown internally. We almost 100\% promote from within. Only for technicians, we recruited experienced ones from outside the company"

Human Resource Manager, Dhanabadee Ceramic

"I recruit internally first. I also support those who have an idea for training"

Assistant Accounting Department Head, Phung Noi Bakery

Also endorsed by a previous study [38], the organizational culture at Thai President Foods was based upon core values and shared vision among its employees. The culture here was supported by internal management development, no-layoff policy and a high staff retention rate. With the internal promotion, its corporate culture and values could continue from one generation to another. There was no layoff because of short-term profits or cost saving. Its corporate culture was nurtured via its long-term orientation and serious concern for its employees.

However, when there is a lack of skills or knowledge in their organizations, the sample SMEs take in outsiders but very carefully to make sure that the outsiders share their core values seriously. Theoretically, sustainable Thai SMEs prefer to promote their own managers from inside in order to continue their corporate culture and underlying values, e.g., [22]. Typically, insiders have firm-specific knowledge and skills which are critical to enhancing organizational capacity to effectively respond to often abrupt market changes, e.g., [21]. Moreover, outsiders, if not selected properly, can come close to destroying the existing strong culture and its underlying values that are important to organizational effectiveness [38]. Therefore, the following proposition is formed for future theory development.

Proposition 3. Internal promotion leads to enhanced corporate sustainability prospect via continuously shared values, firm-specific knowledge and skills preservation and organizational effectiveness. 
4.4. Sustainable Thai SMEs Design Communication Channels to Emphasize The Core Values among Employees Such as Company Poem or Company Song, a Symbol on Employee Uniform and Shared Events

Sustainable Thai SMEs promote communication activities to echo their core values systematically and continuously in employees' hearts and minds. As discussed earlier, Nithi Foods identifies "credible, creative and care" as core values which are printed on employee shirts and office walls so that everyone is reminded of the corporate values all the time. "Credible" means they are trustworthy people. "Creative" means they learn, they think, they innovate. "Care" means they care for each other, the environment and society.

“Our quality control department has a slogan of 'Precise, Quick and Neat'. 'Precise' means accurate and reliable information related to the product quality given by our team. 'Quick' means having a short lead time in servicing our customers, so they have more time to make a decision. 'Neat' means making our product looking good and reliable."

Managing Director, Nithi Foods

"She (Managing Director) always teaches us either through songs, slogans or poems. All of these begin with perseverance ... Everything starts with perseverance."

Administration Department Manager, Phung Noi Bakery

"Our corporate culture is primarily communicated through songs to both teach employees and boost up their morale."

Assistant Sales and Marketing Department Manager, Phung Noi Bakery

"Mostly we work together through our internal activities (e.g. carbon footprint, 4R Program -reuse, recycle, replace and reduce). Everyone is dedicated to achieving our goals. This is Farm Chockchai blood. It is in the blood."

Retail Business Director, Farm Chockchai

"Our company has a project called QCC where people who have creative ideas to reduce waste can propose their ideas. We have cookies as a reward. We develop staff thinking."

Manufacturing Department Manager, Dhanabadee Ceramic

“We have a shared event twice a week called 'Berk Ban Yam Chao' (rise and shine in the morning) which gathers employees together for a morning discussion where we report to employees about corporate news and activities or anything we want to communicate. We also have other channels such as a board."

\section{A Director, Plan Creation}

Previous research supports these findings. At Bathroom Design [22], the ethical value was evident. Employees were paid a higher rate than the industry rate with a promised annual bonus. They were always preached to adhere to the five Buddhist commandments via many shared events. For example, the company frequently invited Buddhist monks to come to preach employees about morality and virtues. Another core value of Bathroom Design was innovation. Bathroom Design really nurtured innovation throughout, including ideas from individual employees gathered via "Creative Saturday", a shared event run every Saturday. Many times, the ideas brought about systematically applying Thai wisdom and local materials in the business, allowing the company to be highly competitive in the world's market.

These findings are also underlined by prior research at True Corporation [36]. True Corporation, a convergent lifestyle enabler, had innovation as a core value. Here, employees lived this value by having plenty of opportunities to express their ideas, so much so that this practice became part of the corporate culture. 
In theory, the sustainable Thai SMEs develop communication channels, such as company poem, company song, symbol on employee uniform and shared events to continuously echo their core values in the employees' minds all the time, e.g., [21]. In particular, these communication channels embed shared values in employees. In turn, the corporate values act as an unwritten rule to guide employees' behaviors, e.g., [27], enabling employees to make desired decisions and thus to prevent undesirable actions. Likewise, during a time of crisis which employees are demotivated, these forms of value communication could effectively lift up their morale and reunite them quickly [36] to work toward recovery. Therefore, the following proposition is formed for future theory development.

Proposition 4. Designing communication channels to emphasize the core values among employees leads to enhanced corporate sustainability prospect through continuously shared values, effective decision making, and a high level of employee morale and motivation.

\subsection{Sustainable Thai SMEs Use the Core Values as Criteria to Recruit New Employees}

The sustainable Thai SMEs have a very strict entry standard to ensure that new recruits fit their corporate cultures. Very careful, they employ many techniques to discover the attitudes and values of job applicants. Once new employees are ensured to share their core values, managers do not have to spend time to unite them behind the core values, and the corporate culture can continue.

"An interview question I often use is whether you have had a big obstacle in your life such as a big family problem or a crisis at work or school. I can spot from their answers whether they had been trying hard to overcome the obstacle or not. We regard a perseverant candidate as consistent with our corporate value."

Managing Director, Nithi Foods

"Persevere to work for a living, don't fly too high, love cleanliness, collect intellects and value harmony. These are the qualifications of our employees. Everyone must have them. "Persevere to work for a living" means everyone must be diligent to work. Everyone must deliver. 'Don't fly too high' means everyone must live a moderate life."

Chairman, Phung Noi Bakery

"We ask them different questions such as whether you are a good people, what it means to be a virtuous person. We ask them to give three examples of when s/he has done good deeds."

Human Resource and Administration Department Manager, Plan Creation

"Chockchai Farm does not encourage unethical persons. That is why you can observe that our employees do not do thefts. If theft happens, we will punish ones who cause it. To get ethical behavior, we have to promote the right employees. If you want to be with us for a long time, you must be honest and straight forward."

Executive Vice President \& Human Resources Strategist, Chockchai Farm

"In the application form, we ask the applicant to inform us about his Facebook account so that we can look up to determine what kind of a person he is. However, this is optional. All of this is only a preliminary screening because we think no one is perfect. If he has some good parts and we can nurture him to be what we desire, we can continue together. If not, that is the end of it."

Managing Director, Dhanabadee Ceramic

Previous research lends support to these findings. At Bathroom Design [22], diligence, perseverance, honesty, integrity, dependability, generosity, frugality and other virtues were given 
priority in its recruitment process. The responsibility for the society and environment as well as "Thainess" comprised the desired personal values. The company's philosophy fostered a corporate culture of respect and collaboration among employees. As part of the culture, employees looked after not only themselves but also one another. In addition, employee performance evaluation criteria included morality and virtues.

Theoretically, sustainable Thai SMEs use the core values as criteria to recruit new employees to make sure they get employees who share the company's direction and existing values. Moreover, selecting employees who do not share the company's direction and values could potentially lead to organizational ineffectiveness where organizational resources are utilized in ways that do not contribute to corporate goals [37]. In a time of crisis, employees who share values and have a relatively high attachment with the company often stay, making it more quickly to recover, e.g., [21]. Therefore, the following proposition is formed for future theory development.

Proposition 5. Using core values as criteria to recruit new employees leads to enhanced corporate sustainability prospect through continuously shared values and a high level of corporate resilience.

\subsection{Sustainable Thai SMEs Avoid an Employee Layoff to Preserve the Core Values Even in Times of Financial Crisis}

In these Thai SMEs, it's not the same in a Western firm. In a Western firm, a staff layoff probably shrinks the workforce size, while the remaining staff is happy to stay. Then, the Western firm expands by recruiting new employees later when an economy picks up. In these SMEs, the cultures and contexts are very different. Instead, a staff layoff causes the remaining staff morale to be shattered. For these SMEs, once their morale is gone, things fall apart. Among them, a strong corporate culture is deeply rooted in organizational history. The highly coherent corporate culture helps these sustainable SMEs to survive difficult financial and social situations during which no employee was laid off.

"We never lay off our employees even in a financial crisis. The difficulty stays only for a short time. If we persevere to solve the problem, we will get through it. We will rebound to where we were or even to a stronger position. Our employees enjoy good times with us, we also go through tough times together."

Managing Director, Nithi Foods

"We could actually purchase a lot of machines. But since we have about 600-800 types of the bakery, if we need to buy machines, how many? One machine can do only one type or a few types at the maximum. Plus, we need a human to monitor them anyway. It is the policy from the Managing Director also that employees are a valuable asset. Each machine can produce according to specifications. One can produce at a maximum of three types of a bakery. But employees can learn to produce new types more and more, so we don't lay off anyone."

\section{Administration Department Manager, Phung Noi Bakery}

“We don't have a layoff policy, but provide a career path for our employees ... We have a clear career path for our employees. For example, temporary workers can be hired as salaried workers. Salaried workers can also become supervisors and department heads."

Factory Director, Plan Creation

“We don't fire people.... No matter how advanced technologies we adopt. We cannot do like what happens in the west because our land is not flat like in the west, but uphill and downhill, so we still need humans to do the work."

Executive Vice President \& Human Resources Strategist, Chockchai Farm 
"We don't lay off employees because we regard everyone as a partner. Everyone should not be put in trouble. When we are happy, we are happy together. When we are in difficulty, we try to help each other."

\section{Managing Director, Dhanabadee Ceramic}

The broader literature supports these findings. At Theptarin Hospital [21], organizational culture was rooted deeply in the history of the hospital. The highly coherent culture enabled the hospital to survive the Asian financial crisis in 1997 during which no employee was laid off. To survive, the salaries of the top and mid-level managers were reduced significantly to save costs for the hospital. Such a reduction was possible only when a very strong teamwork culture exists, demonstrating trust and respect for lower-level employees. This story was told from one generation to another to continue such a culture at the hospital.

Theoretically, when sustainable Thai SMEs avoid an employee layoff, even in times of financial crisis, to preserve their core values, the SMEs essentially enhance their organizational resilience, e.g., $[21,22]$. Keeping employees, who have firm-specific knowledge and skills and share corporate goals and values in times of crisis, helps the SMEs to recover quickly after the economy picks up. While other companies which lay employees off during a crisis have to spend significantly to recruit and train new employees. These sustainable Thai SMEs are ready to pick up with the economy, given that they have employees with firm-specific knowledge and skills, including those knowledge and skills about customers and trade partners, to immediately catch up with the economy. Therefore, the following proposition is formed for future theory development.

Proposition 6. Avoiding an employee layoff leads to enhanced corporate sustainability prospect through continuously shared values and a high level of corporate resilience.

Our coding process has identified six common culture development themes of practices from the interview transcripts and other data collected from the five SMEs. First, they identify a variety of virtues, social and environmental responsibility and innovation as their core values. Second, their top managers always act as a role model according to these values to show their employees how they should live the values. Third, they prefer to grow their own managers to continue their corporate cultures. Forth, they design communication channels to emphasize the core values among employees such as company poem or company song, a symbol on employee uniform and shared events. Fifth, they use the core values as criteria to recruit new employees. Lastly, they avoid an employee layoff to preserve the core values even in times of financial crisis. It can be generalized that to develop a sustainability culture, these SME leaders adopt the six common practices.

\section{Managerial Implications}

Informed by the present study's findings, the following framework, called sustainability culture development, is developed for SME owners who want to develop and maintain a sustainability culture for their organizations. Six best practices constitute this framework.

According to the sustainability culture development framework (Figure 2), SME owners should identify a variety of virtues, social and environmental responsibility and innovation as the corporate core values. This foundation practice must be done first, prior to performing the other five practices. Next, the SME owners should consistently behave as a role model according to these values to show their employees how they should live the values. They should invest to develop their own managers to continue their corporate cultures and design communication channels to emphasize the core values among employees. These communication channels include for example company poems or company songs, and symbols on employee uniforms and shared events. They should also use the core values as criteria to recruit new employees and avoid laying off employees even in times of financial crisis to preserve the core values. SMEs adopting these practices can expect their businesses to be sustainable. 


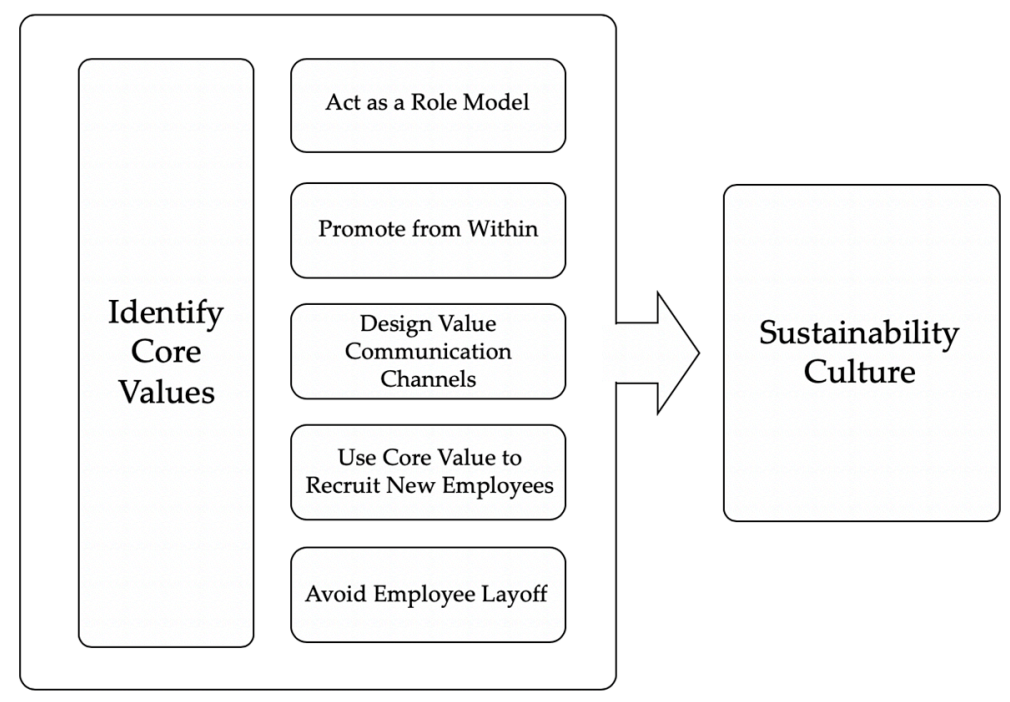

Figure 2. Sustainability Culture Development framework.

\section{Limitations and Future Research}

Although the present study offers some critical insights into culture development for sustainable SMEs in Thailand, it is not without limitations. First, findings from each case enterprise are highly specific to the case enterprise itself, therefore they cannot conveniently be generalized. More research is needed to examine these findings in other organizations in different settings and geographical locations to ensure their external validity. Second, although the multiple data collection methods help to minimize data validity and reliability threats, there may still be conscious or unconscious bias on the interactions between the researchers and interviewees. Therefore, we have provided six propositions for future research to validate our findings and their theoretical assertions in other organizations to inform the future development of a behavioral theory of sustainability culture in organizational settings.

\section{Conclusions}

Adopting the sufficiency economy philosophy framework to draw sustainability culture development practices, the present study reveals six culture development themes of practices that are not being practiced at least among the majority of Thai SMEs. First, sustainable Thai SMEs identify a variety of virtues, social and environmental responsibility and innovation as their core values, a foundation of their corporate cultures. To motivate employees, SME top managers always act as a role model according to the values to show their employees how they should live the values. Consistent behaviors among the top managers reflect their leadership integrity. The SME leaders also prefer to grow their own managers, who already share corporate vision and values, to continue their corporate cultures. To make sure everyone shares the core values, the SME leaders design many communication channels to emphasize the core values among employees, including company songs, poems and shared events. Sustainable Thai SME leaders use the core values as criteria to recruit new employees to make sure new recruits have attitudes consistent with the core values. Lastly, it is difficult to have a strong organizational culture where there is a high staff turnover rate. Therefore, the SME leaders avoid an employee layoff to preserve the core values even in times of financial crisis.

Author Contributions: Conceptualization, N.K. and S.K.; Data curation, S.K.; Formal analysis, N.K. and S.K.; Investigation, N.K. and S.K.; Methodology, N.K. and S.K.; Project administration, S.K.; Resources, S.K.; Validation, N.K. and S.K.; Writing - original draft, N.K. and S.K.; Writing - review \& editing, N.K. and S.K.

Funding: This research received funding support from the Thailand Sustainable Development Foundation.

Conflicts of Interest: The authors declare no conflict of interest. 


\section{References}

1. Grind, K. The Lost Bank, the Story of Washington Mutual-The Biggest Bank Failure in American History; Simon and Schuster: New York, NY, USA, 2012; p. 272.

2. Harter, J.K.; Schmidt, F.L.; Hayes, T.L. Business-unit level relationship between employee satisfaction, employee engagement, and business outcomes: A meta-analysis. J. Appl. Psychol. 2002, 87, 268-279. [CrossRef] [PubMed]

3. Macey, W.H.; Schneider, B.; Barbera, K.M.; Young, S.A. Employee Engagement; Tools for Analysis, Practice, and Competitive Advantage; Wiley-Blackwell: Malden, MA, USA, 2009.

4. National Economic and Social Development Board (NESDB). What is Sufficiency Economy? NESDB: Bangkok, Thailand, 2004.

5. National Economic and Social Development Board (NESDB). Q and A about Sufficiency Economy; NESDB: Bangkok, Thailand, 2004.

6. Allio, R.J. Reinventing management purpose: The radical and virtuous alternatives. Strategy Leadersh. 2011, 39, 4-11. [CrossRef]

7. Brenner, S.; Cochran, P. The stakeholder theory of the firm: Implications for business and society theory and research. IABS Proc. 1991, 2, 449-467. [CrossRef]

8. Donaldson, T.; Preston, L. The stakeholder theory of the corporation: Concepts, evidence, and implications. Acad. Manag. Rev. 1995, 20, 65-91. [CrossRef]

9. Hosseini, J.; Brenner, S. The stakeholder theory of the firm: A methodology to generate value matrix weights. Bus. Ethics Q. 1992, 2, 99-119. [CrossRef]

10. Jones, T.M. Instrumental stakeholder theory: A synthesis of ethics and economics. Acad. Manag. Rev. 1995, 20, 404-437. [CrossRef]

11. Wood, D. Corporate social performance revisited. Acad. Manag. Rev. 1991, 16, 691-718. [CrossRef]

12. Piboolsravut, P. Sufficiency Economy. Asean Econ. Bull. 2004, 21, 127-134. [CrossRef]

13. Phillips, R.; Freeman, R.E.; Wicks, A.C. What stakeholder theory is not. Bus. Ethics Q. 2003, 13, 479-502. [CrossRef]

14. Avery, G.C.; Bergsteiner, H. Honeybees E Locusts: The Business Case for Sustainable Leadership; Allen \& Unwin: Sydney, Australia, 2010.

15. Avery, G.C.; Bergsteiner, H. Sustainable Leadership: Honeybee and Locust Approaches; International Version; Routledge: Abingdon-on-Thames, UK, 2011.

16. Oruc, I.; Sarikaya, M. Normative stakeholder theory in relation to ethics of care. Soc. Responsib. J. 2011, 7, 381-392. [CrossRef]

17. Wong, L.; Avery, G.C. Creating sustainability in organizations: Beyond being green. Int. J. Interdiscip. Soc. Sci. 2008, 3, 68-74.

18. Puntasen, A.; Premchuen, S.; Keitdejpunya, P. Application of the royal thought about the Sufficiency Economy in SMEs; Thailand Research Fund: Bangkok, Thailand, 2003.

19. Kantabutra, S.; Associates. Sufficiency Economy Leadership Practices; Thailand Research Fund: Bangkok, Thailand, 2010.

20. Kantabutra, S. Sufficiency Economy in Business for Sustainability; National Institute of Development Administration: Bangkok, Thailand, 2010.

21. Kantabutra, S. Sustainable leadership in a Thai healthcare services provider. Int. J. Health Care Qual. Assur. 2011, 24, 67-80. [CrossRef]

22. Kantabutra, S. Putting Rhineland principles into practice in Thailand: Sustainable leadership at Bathroom Design company. Glob. Bus. Organ. Excell. 2012, 31, 6-19. [CrossRef]

23. Kantabutra, S.; Suriyankietkaew, S. Sustainable leadership: Rhineland practices at a Thai small enterprise. Int. J. Entrep. Small Bus. 2013, 19, 77-94. [CrossRef]

24. Kantabutra, S.; Thepa-Apiraks, T. Sustainable leadership and consequences at Thailand's Kasikornbank. Int. J. Bus. Innov. Res. 2016, 11, 253-273. [CrossRef]

25. Tuan, L.T. An air-flight ticket agency with sustainable leadership. J. Manag. Sustain. 2012, 2, $210-216$.

26. Ulrich, D.; Brockbank, W. Creating a winning culture: Next step for leading HR professionals. Strateg. HR Rev. 2016, 15, 51-56. [CrossRef] 
27. Flamholtz, E.G.; Randle, Y. Corporate Culture, Business Models, Competitive Advantage, Strategic Assets and the Bottom Line: Theoretical and Measurement Issues. J. Hum. Resour. Costing Account. 2012, 16, 76-94. [CrossRef]

28. Tàpies, J.; Moya, M.F. Values and longevity in family business: Evidence from a cross-cultural analysis. J. Fam. Bus. Manag. 2012, 2, 130-146. [CrossRef]

29. Kantabutra, S.; Avery, G.C. Sustainable leadership at Siam Cement Group. J. Bus. Strategy 2011, 32, 32-41. [CrossRef]

30. Kantabutra, S. Measuring corporate sustainability: A Thai approach. Meas. Bus. Excell. 2014, 18, 73-88. [CrossRef]

31. Kantabutra, S. Exploring the corporate sustainability process: A Thai perspective. Int. J. Product. Qual. Manag. 2017, 22, 16-40. [CrossRef]

32. Kantabutra, S. A Thai Rhineland leadership model: In search for corporate sustainability model for Asia. Int. J. Bus. Excell. 2017, 13, 16-40. [CrossRef]

33. Glaser, B.G.; Strauss, A.L. The Discovery of Grounded Theory; Aldine Publishing: Chicago, IL, USA, 1967.

34. Parker, L.D.; Roffey, B.H. Methodological Themes: Back to the Drawing Board: Revisiting Grounded Theory and the Everyday Accountant's and Manager's Reality. Account. Audit. Account. J. 1997, 10, $212-247$. [CrossRef]

35. Strauss, A.L.; Corbin, J. Basics of Qualitative Research: Grounded Theory Procedures and Techniques; Sage Publications: Thousand Oaks, CA, USA, 1990.

36. Kantabutra, S. Sweet success beyond the triple bottom line: Honeybee practices lead to sustainable leadership at Thailand's True Corp. Glob. Bus. Organ. Excell. 2012, 30, 22-39. [CrossRef]

37. Senge, P.M. The Fifth Discipline: The Art and Practice of the Learning Organization; Currency Doubleday: New York, NY, USA, 1990.

38. Kantabutra, S. Sustainable leadership at Thai President Foods. Int. J. Bus. 2014, 19, 152-172.

(C) 2019 by the authors. Licensee MDPI, Basel, Switzerland. This article is an open access article distributed under the terms and conditions of the Creative Commons Attribution (CC BY) license (http://creativecommons.org/licenses/by/4.0/). 